\title{
The Development Model of Evaluation and Audit Internal Quality in University of Sumatera Utara
}

\author{
Dedi Amrizal \\ Education of Management \\ Postgraduate Programe in Universitas Negeri Medan, FISIP \\ University of Muhammadiyah Sumatera Utara \\ Medan, Indonesia
}

\author{
Saiful Sagala \\ Education of Management \\ Postgraduate Programe in Universitas Negeri Medan \\ Medan, Indonesia
}

\begin{abstract}
Internal quality evaluation and audit did not contribute effectively to the implementation of quality assurance at University of Sumatera Utara (USU). The purposes of the research were: to investigate the implementation of the internal quality assurance system, to evaluate the quality commitment as well as quality culture, and to examine the implementation of evaluation and audit of the quality assurance system in USU. This study applied descriptive qualitative method. The data were collected by using interview, observation and documentary technique. The informants of this research were thestaffs of Quality Assurance in university and study program level; the deans and the chairmen of study program at USU. The result revealed that the internal quality assurance system utilized various models of quality documents based on the understanding of staffs of each faculty and study program. Besides, theinternal quality management was still implemented at the level of faculty. On the other hand, the implementation of evaluation of the internal qualityofthe quality assurance system of faculty and the student program level was not in accordance with the quality assurance guidance documents. In addition, the implementation of quality audit by the auditor was not appropriate to the guidance and most of the reports of auditing were not comprehensive. It can be concluded that the quality cycles have been implemented, but statements contained in the accreditation form have not been actualized in managerial and academic activities. The implementation of quality evaluation was not fully successful in investigating the basic shortcomings that must be addressed by the faculty and the study program.
\end{abstract}

Keywords-evaluating, audit, quality evaluation,quality audit and internal quality management

\section{INTRODUCTION}

In managing organizational resources in higher education, a leader often findsimperfect achievement such as: completion of the task which is not on time, ineffective use of funds, inappropriate placement of human resources, and other things related to the problems of higher education organizations. To overcome the problems, the leader should conduct the monitoring, evaluating, correcting, warning, and alignment activities in accordance with the needs of the organization in order not to deviate from the planning that has been made before.

Basically, all these activities are the application of supervisory functions as an effort to improve the quality of management within the organization. Robbin (Sugandha,
1999) states that controlling is a very basic process of activity and it requiresamanager to perform the tasks and work of the organization. Controlling can be classified into three (1) controlling as a planning guidance and it contains the process ofmoiitoring and executing against deviations that occurs in the organizational process; (2) controlling as measurement of achievement that can be used to the planning and to take necessary corrective actions to achieve the goals of the organization; (3) controlling as a performance booster is an ongoing effort to monitor the programs, projects and activities that an organization is implementing in order for its performance to run as it should be. (Winardi, 2000; Kadarisman, 2013; Suripto, 2013, Terry and Rue; 2012, Lapian, 2012; Hasbullah, 2015; Wibowo 2006).

The implementation of controlling in quality assurance system can be in the form of : (1) monitoring, is measurable activity of a continuous management process of the implementation of a project or activity that has been planned previously Rivai 2008; Manullang, 2002; Zahid, 2005); (2) evaluation, is a process to analyze and assess a condition or program, whether the program has been running according to its purpose or not. (Wirawan, 2015; Arikunto, 2015; Sukardi, 2011); and (3) audit, is a systemic process that contains the accumulation and evaluation of evidence of information to determine and report the degree of correspondence between information and criteria established by competent and independent persons (Arens et al., 2012; Messier et al., 2014; Sukrisno, 2012).

Monitoring, evaluation and audit are the application of supervisory functions in quality management.The results of an evaluation in an institution can be obtained by conducting a detailed and fundamental audit.Audit activity is an activity of comparing quality standard and the actual condition in organization.

Pratono (2011) argues that the activity of evaluation makes the internal control lead to the improvement on quality service. Operational audits conducted related to the implementation of standard operating procedures provide effective input to the work unit related to service activities provided. Furthermore, colleges also require quality audits. Becket (2005) discloses that audits performed have potential values in improving the quality of higher education provision and identifying actions that colleges and departments can take. 
The above research reveals that evaluation activities are important because they can improve the quality, while the audit is also required to conduct inspection activities in the broad sense of the implementation of the quality standards of an organization, system, process, product, or activities carried out by the competent objectively and impartially. A best supervisory model is an important choice to oversee the planning so that the previously formulated operational standards procedures are well executed.

All organizational activities and programs that run on quality use evaluation and audits to facilitate the achievement of organizational goals. In fact, it shows that higher education management in USU uses controlling as one of the stages (cycles) of work. USU applies the PDCA cycle (Plan, Do, Check, and Action). The supervisory function of this cycle lies in the Check stage which is shown in the activities of monitoring, evaluating and quality auditing to supervise the implementation of SPMI (Internal Quality Assurance System).

Basically, quality assurance at the faculty and study program level has been guided to make the process of establishing and fulfilling the quality standard of management of higher education consistently and continuously. The end points of the quality assurance process to make the stakeholders (both students, lecturers, educators, parents, the world of work, government, and other interested parties) gain satisfaction and achieve their desires. Information from faculty leaders (interview in June 2017) states that before reaching the final process, the evaluation or audit must be done so that the quality of performance and quality management can be measured and the weakness can be detected.

Referring to the results of previous research and preliminary study, it reveals that evaluation and quality audit are the activities that can describe the quality of higher education. The Implementation of internal quality evaluation and audit has not been fully run and provides benefits because of: (1) the existing documents have not been fully applied in the faculty andstudy program level; (2) the lack of socialization and comprehension of quality by the leaders of study programs, lectures, and educational staffs result in the low commitment and makes the quality culture not yet established; (3) the evaluation is not based on the needs and problems of faculty and study program (only for the needs of accreditation forms). In addition, internal audit quality was not considered by the elements of faculty leadership because of lack of benefits for the implementation of quality.

The issues of evaluation and internal audit faced by higher education organizations are currently associated with the implementation of internal quality assurance as reflected in standard operating procedures that do not yet reflect actual conditionsand if there is any, it has not been implemented in earnest. The implementation of internal quality evaluation is done with a modest and its only formality of work routine. The last, the implementation of audit was not considered as a measure of the success rate of the implementation of the quality standard that has been done.

This study focuses on evaluation and audit because it contains investigative actions and high responsibility. Based on this background, this research tries to reveal the need for the development of evaluation model and internal quality audit at USU.

\section{METHOD}

This research uses descriptive qualitative method which aims to dig up the information relating to the implemantation of evaluation and audit of quality assurance system in USU. Data were obtained through participant observation, in-depth interviews, and document studies on the internal quality assurance system.

Data collection is focused on internal quality evaluation and audit that includes the following : (1) the implementation of internal quality assurance system; (2) commitment and quality culture; (3) the implementation of internal quality evaluation in the preparation of documents, procurement of quality documents, and implementation of quality documents and implementation of internal quality audits in the implementation of quality policy, implementation of quality standards and implementation of operational standards procedures. The validity of data obtained from observation, interview, and document study is done through credibility test or trust to research data is done with triangulation (checking data from different types of sources in various ways and various deadlines), confirmability (research is stated to be objective when the results of research have been agreed upon by many people), dependability (conducting an audit of the entire research process by an independent counselorand transfersability (making reports with detailed, clear, systematic, and reliable descriptions so that others can understand the research results so as to have the possibility to apply the results of the research).

\section{FINDING AND DISCUSSION}

The academic quality assurance system at USU is designed, implemented and supervised through monitoring, evaluation or audit to ensure the quality of the awarded academic degree is maintained.

Continuous quality improvement according to USU's Quality Management Unithas been done through: (1) controlling in the form of internal monitoring conducted from UMM ( Quality Management Unit at university level) to GJM (Quality Assurance Circle at faculty level), then continue from GJM (Quality Assurance Circle) to GKM (Quality Control Circle at study program level) throughout the cycle (process) takes place; (2) controling in the form of internal evaluation is done from the study program (GKM) to teaching staffs, laboratoty staffs and educational staffs in study program throughout the cycle (process) takes place; (3) controling at the final stage is carried out through the Internal Quality Audit (AMI) as a whole to compare all implementations with the standards set forth in the quality document. It includes checking the quality objectives of the cycle by keeping referring to the early baseline of the cycle (even the baseline for the last four years. AMI is conducted by a group of quality auditors who have internal certification.One group consisted of 2-3 quality auditors appointed by Rector with tenure of 3 months. So, the internal quality audit at USU is independent and formal. Each group of auditorsmakes an AMI report of each auditee that it audits separately. The output from AMI is 
a Proposed Corrective Action (Utikor) also called Corrective Action Request (CAR) which is a recommendation from the AMI report.

In fact, it indicates that quality documents at Universitary level (academic quality policy, quality manual, procedure manual, and quality standard ) and quality document at faculty level (academic quality policy, quality manual, and academic faculty procedure manual, academic quality standard of faculty, and other academic guidebook) have not been fully socialized to lecturers, educators and students. Preparation and implementation of quality document is still limited for the purposes of accreditation forms. The spirit of quality and commitment to quality implementation has not been well established. This shows that quality culture is difficult to establish under these conditions.

Furthermore, the quality evaluation activities undertaken so far are only to complement accreditation forms.In line with that, the internal quality audit activities that are always done at the end of the year are less well received by faculty and study program because they do not involve them in the process and the results are felt less to address their basic needs and problems incarrying out quality assurance.

All the conditions mentioned above can be explained as follows:

\section{Implementation of internal quality assurance system}

UMM USU has published guidelines for the preparation of quality documents, and GJM and GKM prepare quality documents at the faculty and the study program level.The results of this research indicate that the lecturers in preparing the learning tools have not been referring to the existing quality documents. The lecturers prepare learning tools based on their personal experiences. This data shows that internal quality management has not been implemented properly.

\section{Commitment and Quality Culture}

The making of the college contract, syllabus and semester learning plansis only as a semester routine that the lecturer does without considering the guidelines and the provisions of the written document. On the other hand, monitoring the presence of lecturers / students, the application of curriculum, test-making, test preparation and others have not been used as a means of monitoring and evaluation of routine activities.

This condition makes a low quality commitment from the point of learning and academic administration because of the lack of quality understanding of lecturers, educational staffs and students.

The lack of socialization on the application of quality documents makes quality commitment difficult to be realized in the learning process and academic administration. So the quality documents that have been prepared at the time of accreditation form difficult to realize due to weak socialization that makes the quality culture is not visible in the life of the campus.

3. The Implementationof evaluation and internal quality Audit
Faculty and study program conduct the evaluation of internal quality management to complete the accreditation requirement. Implementation achievements and measuring indicators for faculty and study program's quality documents are made not based on existing conditions and for correcting errors found, starting from the implementation of learning, administrative processes, research, community service and cooperation are evaluated in accordance with the needs of accreditation forms.

Members of faculty and study program perceive that the implementation of internal quality management audit that UMM routinely conducts every year through selected auditors is not much help them in applying quality. The recommendations given by faculty leaders were not responded and not followed up by university and UMM.

The implementation of the USU's quality assurance is a general description of higher education in North Sumatra nowadays. Related to this, Hamzah and Rahman (2002) have revealed that the process of teaching and learning in universities still needs a lot of improvement and structuring.

The existing learning process is tedious, routine, run mechanically / rigidly, and losing pedagogical nuances, whereas quality assurance activities are done is considered maximum. This condition indicates that quality management has not gone well, lack of funds, and low quality spirit at the faculty and program study level. This is in line with Basuki's (2004) disclosure that the implementation of the quality assurance system in the learning process at the departmental level is working and is successful if supported by committed perpetrators, good management with measurable indicators, and adequate funding support.

The implementation of quality assurance at USU should pay attention to improving the implementation of an internal quality assurance system in faculty and study program, taking into account the commitment of quality to the establishment of quality culture, and measuring quality implementation through correct evaluation and quality audit.

\section{Implementation of Internal Quality Assurance System}

The implementation of internal quality assurance should be an independent activity of the university because it has different specifications in terms of size, structure, resources, vision and mission, history, and leadership. It is written in documents produced at the university, faculty and study program levels. This document will serve as the basis for the implementation of internal quality management as described in the guidelines for the implementation of quality assurance systems for universities to study programs. (Lubis, 2010; Rosmayanti, 2016).

Based on the observations it was found that revisions and document improvements made in each quality cycle were not based on the track record performed from the previous cycle . In addition, the implementation of the learning process and academic management have not fully used the document as a guide in the move. Inadequate document socialization to lecturers, education staff and students make them not make quality as a necessity in their daily activities. 
To overcome the above problems, UMM not only provides guidance, conducts training and an annual audit only, but needs to provide assistance to the making and dissemination of quality documents and pay attention to the problems conveyed by the faculty and study program in terms of internal quality assurance. UMM image must be improved, not only as a tool, but as a partner in running the quality. In this regard, the implementation of the making and the socialization of the documents in the faculties andthe study program must receive adequate funding allocations.

\section{Building Quality Commitment and Quality Culture}

Building quality commitment and quality culture at the faculty level and study program is not easy if the document is not used as a daily work guide by lecturers and education personnel. Understanding of quality is only limited to leaders at the faculty level and the implementation of quality has not been a concern to the leadership of study program , educational staffs and students. This is due to the lack of socialization of documents and the existence of documents only as a complement to accreditation only.

UMM will need to make quality awareness to be the main agenda of faculty and study program for learning and academic activities in the future. Monitoring and evaluation itself is the best option to double-check reports of daily activities that have been reported.

\section{Implementation of Evaluation and internal quality Audit}

Agenda for evaluation and internal quality management audit has been done in accordance with the provisions of UMM. UMM conducts annual checks related to the preparation of documents and evaluation execution. But the quality of the implementation of internal quality management and quality evaluation of quality management has not been considered.

Reports regarding quality evaluation related to the implementation and continuation of quality management in the faculty and study program are only formalities. This is due to the complaints of faculty and study program through quality evaluation and quality audit has not been seriously responded by UMM or university.

The faculty considers that the implementation of internal quality audit conducted by UMM through the auditor is less useful and has no connection with the faculty. UMM must build awareness of the importance of evaluation and audit. Evaluation and quality audit are built into two complementary and synergized matters to support the internal quality assurance system.

\section{CONCLUSION AND SUGGESTION}

\section{A. Conclusion}

The implementation of Internal Quality Management in the learning sector and academic administration requires evaluation and internal quality audit that is capable of measuring achievements that have been obtained. So far, the implementation still leaves problems to be solved at the faculty and program study level, starting from the implementation of preparing the document, document implementation, the seriousness and commitment to implement the quality, and the weakness of evaluation of learning activities and academic administration. UMM should hold improvements at the faculty and study program levels through GKM and GJM on the issues that are found.

The key to the problem lies in the document that is not used as a guide in learning and academic administration that causes the lack of quality commitment and quality awareness that is not known because of the ineffectiveness of quality evaluation conducted by faculty and study program. UMM as a quality guard at the university level should perform mentoring and escorting from document creation to evaluation of document implementation.

Initial awareness needs to be built on the evaluation and audit models being undertaken. The next evaluation models and quality audits should help strengthen document creation and implementation and build awareness of lecturers, educational staffs and students in implementing quality.

\section{B. Suggestion}

It is necessary to develop evaluation models and quality management audits that can evaluate the weaknesses and audit the implementation of quality standards built in each quality assurance cycle.In addition, more real and direct quality facilitation to faculty and study program must be done by UMM.

\section{ACKNOWLEDGMENT}

This paper will not be finished without the help of various parties. I am very grateful to the leadership of UMM USU. which helps a lot in obtaining data from this research. I would also like to thank the leaders of faculty, lecturers and employees of USU who are very helpful in providing information related to this research. I hope this paper can be useful and help USU in implementing internal quality assurance, especially the implementation of internal quality evaluation and audit. The new model of evaluation and quality audit at USU should be able to overcome the problems in implementing quality assurance.

\section{REFERENCES}

[1] Sugandha, Dann, "Kepemimpinan di dalam organisasi. Cetakan Kedua". Bandung: Sinar Baru. 1999. pp. 150.

[2] Winardi, J,"Manajemen Perilaku Organisasi” (Cetakan Pertama), Jakarta: Penerbit Prenada Media, 2000, pp. 585.

[3] Kadarisman, M, "Manajemen Pengembangan Sumber Daya Manusia", Jakarta: Rajawali Pers, 2013, pp. 174.

[4] Suripto, Bambang, "Akuntasi Managemen”, Yogyakarta: Salemba Empat,2013, pp. 8.

[5] Lapian, Gandhi, "Disiplin Hukum Yang Mewujudkan Kesetaraan Dan Keadilan Gender”, Jakarta: Yayasan PustakaObor Indonesia, 2012, pp. 182.

[6] Terry, George R. dan Leslie W. Rue, "Dasar-Dasar Manajemen" (Cetakan Ketiga Belas), Jakarta: Bumi Aksara, 2012, pp. 10.

[7] Hasbullah, "Kebijakan Pendidikan”,Jakarta: Rajawali Pers, 2015, pp. 115

[8] Wibowo, “Manajemen Perubahan”, Jakart: Raja Grafindo Persada, 2006, pp. 14

[9] Rivai, Veitzal, “Islamic Financial Management” Jakarta: PT. Raja Grafindo Persada, 2008, pp. 488-489.

[10] Manullang, M., “Manajemen”, Yogyakarta: UGM Press, 2002, pp. 173. 
[11] Zahid, S.J. Anwar, "Rural Development Planning and Project Management in Bangladesh", Minnesota:University of Minnesota, 2005 , pp. 26.

[12] Wirawan, "Manajemen Sumber Daya Manusia Indonesia", Jakarta: PT.Raja Grafindo Persada, 2015, pp.38.

[13] Arikunto, Suharsimi, "Dasar-dasar Evaluasi Pendidikan”, Jakarta: Bumi Aksara, 2015, pp. 25.

[14] Sukardi, H. M.,"Evaluasi Pendidikan”,Yogyakarta: BumiAksara, 2011, pp. 22.

[15] Arens, Alvin A., Mark S. Beasley dan Randal J. Elder, "Auditing and Assurance Services: An Integrated Approach, 1.3th Edition, London: Pearson Prentice Hall, 2012, pp.4.

[16] Messier, William F., Steven M. Glover, dan Douglas F. Prawitt, "Jasa Audit dan Assurance: Edisi 8", Jakarta: Selemba Empat, 2014, pp.12.

[17] Sukrisno, Agoes," Auditing. Edisi 4", Jakarta: Salemba Empat, 2012, pp. 4
[18] Pratono, Rudi, "Evaluasi Efektivitas Pelaksanaan Audit Operasional Aktivitas Pelayanan Jasa Penginapan Pada Hotel Equator Surabaya", Aktual Jurnal Akuntansi 3 (1), 2011, pp. 86-33.

[19] Becket, Nina, “Analysing Quality Audits in Higher Education”, Brookes e-Journal of Learning Vol. One - Issue Two - Jan 2005.

[20] Hamzah dan A. Rahman, "Peningkatan Kemampuan Mahasiswa untuk Belajar Mandiri pada Mata Kuliah Geografi melalui Penulisan Jurnal Perkuliahan”, Jurnal Ilmu Pendidikan. 9. (2), 2002, pp. 142-150.

[21] Basuki, Ari, "Implementasi Sistem Jaminan Mutu (Quality Assurance) Proses Pembelajaran Di Perguruan Tinggi. Jurnal Penelitian Dan Evaluasi Pendidikan", Nomor 1, Tahun VI, 2004, pp. 104-113.

[22] Lubis, Chairul P. dkk, "Implementation of Quality Assurance for Higer Education USU experience and Program” Medan: USU Press, 2010, pp. 7-14.

[23] Rosmayati, dkk, "Panduan Persiapan Dokumen Pendukung Dan Lampiran Borang Akreditasi Program Pasca Sarjana (S2\&S3)", Medan: USU Press, 2016, pp. 14-17. 